Canadian University Music Review

Canadian University Music Review

Revue de musique des universités canadiennes

\title{
Paul Robinson. Ludwig van Beethoven: Fidelio. Cambridge Opera Handbooks. Cambridge: Cambridge University Press, 1996. xi, 191 pp. ISBN 0-521-45852-8 (hardcover)
}

\section{Alison Stonehouse}

Volume 20, numéro 1, 1999

URI : https://id.erudit.org/iderudit/1015656ar

DOI : https://doi.org/10.7202/1015656ar

Aller au sommaire du numéro

Éditeur(s)

Canadian University Music Society / Société de musique des universités canadiennes

ISSN

0710-0353 (imprimé)

2291-2436 (numérique)

Découvrir la revue

Citer ce compte rendu

Stonehouse, A. (1999). Compte rendu de [Paul Robinson. Ludwig van Beethoven: Fidelio. Cambridge Opera Handbooks. Cambridge: Cambridge University Press, 1996. xi, 191 pp. ISBN 0-521-45852-8 (hardcover)]. Canadian University Music Review / Revue de musique des universités canadiennes, 20(1), 131-133. https://doi.org/10.7202/1015656ar

All Rights Reserved (c Canadian University Music Society / Société de musique des universités canadiennes, 2000
Ce document est protégé par la loi sur le droit d'auteur. L’utilisation des services d'Érudit (y compris la reproduction) est assujettie à sa politique d'utilisation que vous pouvez consulter en ligne.

https://apropos.erudit.org/fr/usagers/politique-dutilisation/ 
Paul Robinson. Ludwig van Beethoven: Fidelio. Cambridge Opera Handbooks. Cambridge: Cambridge University Press, 1996. xi, 191 pp. ISBN 0-521-458528 (hardcover).

With its series of Cambridge Opera Handbooks and Cambridge Music Handbooks, Cambridge University Press provides a valuable service. Both series are directed towards both students and concert- or opera-goers, and are intended to serve as an introduction to, as well as a possible precursor of further study of, the work under consideration. All follow the same general organization, consisting of historical, analytical, and bibliographic/discographic sections. A Cambridge Opera Handbook will typically begin with an account of the sources and inspiration for the opera, and a delineation of the collaboration between composer and librettist. This is followed by a full synopsis, including an analysis of each number, sometimes brief, sometimes extensive. The balance of each handbook is taken up with essays on some aspect of the opera, a performance history and a bibliography and guide to further study. This is the formula followed by Paul Robinson's handbook on Fidelio.

As Beethoven's only opera, Fidelio occupies a unique position in music history. For just that reason, it has been subject to much analysis, in which his compositional techniques are compared with those used in his other works, and his operatic techniques with those of Mozart on the one hand, and of French composers like Cherubini and Pierre Gaveaux, composer of the first opera on this subject, on the other. In his introduction, Robinson discusses these issues, and addresses the philosophical underpinnings of the opera. It is his own belief that the opera is an unashamedly ideological and moral statement, that the moral aspect is of far greater import than the narrative, and that belief underlies much of this book, including the synopsis chapter. Robinson often reads Beethoven's own ideals (or idealism) into those of the characters he portrays in music. This is beyond question when it comes to the music sung by Leonore or Florestan, but he is, it seems to me, on rather less solid ground when he claims that "the prisoners' chorus is the opera's ideological core" (p. 14). Certainly, this chorus is a metaphor-besides being highly effective dramatically - but surely the ideological core lies in Leonore as the personification of Beethoven's idealism. Apart from this small complaint, however, the synopsis provides a clearly explained and uncomplicated summary of the musical essence of the opera, an excellent departure point for further analysis.

Such analysis is provided in chapter 6 , in which Michael Tusa considers the structure, style and process(es) involved in the composition of Fidelio. After a consideration of the key structures of the three versions, Tusa addresses Beethoven's use of form and musical conventions, and shows that he complied with those in common use in Vienna, where by convention the strophic forms of Singspiel were used for simple characters like Rocco, while the more complex forms of opera seria or opéra comique arias were given to the upper-class hero and heroine, Leonore and Florestan. His analysis of the music assigned Pizarro is particularly interesting: Tusa shows that in order to reflect the duality of his nature (the public upholder of order vis-à-vis the private villain), Beethoven uses regular formal structures (the outward appearance) 
which he then disrupts tonally, harmonically and rhythmically (the inner reality). To cite one example: Tusa offers a detailed analysis of the aria, "Ha, welch' ein Augenblick!" In the form of a conventional sonata without development in D major/minor, he shows that the aria ranges tonally, even within sections, as far as E-flat major, with a startling shift during the recapitulation from $\mathrm{E}$ flat to $\mathrm{A}$ functioning as the dominant of $\mathrm{D}$. Diminished harmonies and stepwise chromatic ascents and descents in the bass serve further to blur the tonal stability. Robinson provides examples from other parts of the opera to show that stepwise chromatic movement is a musical allusion to Pizarro.

Joseph Kerman continues the musical analysis of Fidelio in the next chapter with a consideration of the use, musical and textual, of the word "Augenblick" (moment), which appears, he contends, "with almost embarrassing frequency" (p. 132). Its widespread use alone provides reason enough for extensive analysis, and he extends the reasoning to include moments that he considers worthy of further examination, like the act 1 quartet.

Two chapters are given over to a consideration of the relationship between French opera and Fidelio. David Charlton provides an essay on its French operatic and politico-operatic origins. He uses his encyclopaedic knowledge of the genre to trace various narrative threads in Fidelio-unjust detention, a courageous and loving woman, cross-dressed female roles, the power of conjugal love-back to opéras comiques performed as early as the 1760 s, and finds fertile ground for further comparison in the revolutionary operas of the 1790s, when "any serious fiction deploying a prison scene ... carried the whole conceptual and emotional burden of 1789" (p. 57). Musical antecedents abound also, and Charlton provides examples of prisoners' choruses and the use of the same or similar keys to set similar sentiments. This chapter is followed by Robinson's essay on Fidelio and the French Revolution. Here he expands on his thesis, that this is above all a work of ideology, for "it cannot simply be about a wife rescuing her husband" (p. 69). Robinson deals quickly with a number of different psychological readings of Fidelio before taking up his main point, alluded to above, which is the musical depiction of freedom in the Prisoners' Chorus and elsewhere. For Beethoven, he concludes, freedom is both a concrete, i.e., musically characterizable, and an abstract concept. Each time the word "free" is heard, it is imbued with special and unmistakable musical significance. As for the abstract, Robinson contends that the entire opera can be read as a metaphor for freedom through revolution, a metamorphosis from the dark old prison order at the beginning of act 1, through the cataclysm of change itself, to the freedom of a bright new society by the end. It is in this essay that Robinson is at his most persuasive, and he provides substantial musical support for his points.

Two more chapters round out this handbook. The first is Winton Dean's essay, "Beethoven and Opera," reprinted from The Beethoven Handbook, edited by Denis Arnold and Nigel Fortune (London: Faber, 1971). This is an historical account of the writing of Fidelio, which begins with Beethoven's earliest introductions to opera, followed by his arrival in Vienna, the story of his introduction to his French model, and a brief recounting of the three versions of the opera. The last chapter is entitled "An Interpretative History"; 
it is an overview of performances of and performers in Fidelio. It offers a chronicle of the stagings of this opera from its premiere in 1805 , threatened by Napoleon's occupation of Vienna, through interpretations by Alfred Roller (conducted by Gustav Mahler) and Wieland Wagner, to that of Jonathan Miller, first performed in 1982 and conducted by Roger Norrington. Robinson shows that productions of Fidelio have gone full circle, with the most recent attempting a return to the world in which it premiered, that of the French Revolution.

Paul Robinson's Fidelio is a worthy addition to the series of Cambridge Opera Handbooks. It follows the concept and design of its predecessors, and is easily their equal in terms of scholarly level and readability, while still permitting the author licence to impose something of his personal stamp on the interpretative process. It provides the mid-level student with an introduction to one of the most eminent achievements of the operatic world, while pointing the way to further research for those who wish to pursue the topic further.

Alison Stonehouse

Léonard A. Rosmarin. When Literature Becomes Opera : Study of a Transformational Process. Amsterdam et Atlanta : Rodopi, 1999. 160 p. ISBN 90-420-0694-3.

Dans cet ouvrage, Léonard Rosmarin cherche à montrer quels sont les principes qui président au phénomène de transformation d'un texte littéraire en livret d'opéra. Afin de mener à bien son objectif, l'auteur propose l'étude de huit livrets d'opéra parmi les plus célèbres du répertoire et qui s'inspirent tous d'auteurs français des $\mathrm{XIX}^{\mathrm{e}}$ et $\mathrm{XX}^{\mathrm{e}}$ siècles : Rigoletto, La traviata, Carmen, Thaïs, La bohème, Tosca, Pelléas et Mélisande et Dialogues des Carmélites. L'étude se compose de deux parties de longueur à peu près égale. Dans le premier chapitre, "Reinforcing the Centre of Gravity », Rosmarin dégage les principales différences entre les livrets et les œuvres les ayant inspirés. Il décrit comment les librettistes ont nécessairement dû élaguer les œuvres littéraires pour mettre l'accent sur un aspect, ce centre de gravité autour duquel gravitent tous les éléments retenus ou modifiés par rapport aux textes originaux. Ainsi, Rosmarin montre que Rigoletto s'articule tout entier autour de la malédiction de Monterone ou que Dialogues des Carmélites développe principalement le thème du transfert de la grâce. Rosmarin s'étant limité à l'étude de chefs-d'œuvre de l'histoire de l'opéra, on aurait tort de lui reprocher son enthousiasme en regard du travail d'adaptation de Piave, Gallet ou Meilhac et Halévy. Il a également tout à fait raison d'insister sur le pouvoir expressif de la musique, qui supplée amplement à ce que le livret doit passer sous silence, notamment dans le cas de Thaïs. Je ne puis cependant souscrire à tous ses jugements d'ordre littéraire, en particulier en ce qui concerne Victor Hugo, qu'il écorche au passage en affirmant que sa production théâtrale est mélodramatique dans le sens péjoratif du terme (p. 15). Ce genre de remarque ignore que le drame romantique est très voisin du mélodrame et que, de plus, presque toute l'œuvre de Verdi ressortit précisément à cette esthétique du mélodrame très en vogue 